\title{
Simplifying the complex: an 'Ecosystem Principles Approach' to goods and services management in marine coastal ecosystems
}

\author{
M. Townsend ${ }^{1, *}$, S. F. Thrush ${ }^{1}$, M. J. Carbines ${ }^{2, * *}$ \\ ${ }^{1}$ National Institute of Water and Atmospheric Research, Hamilton 3216, New Zealand \\ ${ }^{2}$ Auckland Council, Auckland 1142, New Zealand
}

\begin{abstract}
The ability to manage complex systems effectively must stem from simplifications of ecological knowledge. We present a technique called the 'Ecosystem Principles Approach' (EPA) as a progressive way of incorporating ecology into goods and services assessments. The EPA moves away from the complexity of ecosystem functions and focuses on general ecological principles. These principles more explicitly define key elements of system functioning, are not spatially or temporally confined, and can be utilised in assessment and decision-making processes. When applied to a coastal system in New Zealand, the EPA highlighted that services were primarily dependent on connectivity and that the maintenance of healthy intertidal areas was highly important for system functioning. The approach also demonstrated a separation between locations where ecosystem functions were generated and where services were valued. A high level of multi-functionality and connectivity between goods and services in marine coastal systems suggests services should be managed collectively rather than individually. The strength of the EPA is that it aligns to the principles of 'EcosystemBased Management'. This approach demonstrates how ecological information can be simplified into a format that can advise policy and better integrate with management. It highlights the need for greater trans-disciplinary integration of ecology and social science to better understand how human interactions result in critical community shifts and loss of resilience.
\end{abstract}

KEY WORDS: Complexity - Ecosystem-based management - Ecosystem functions - Ecosystem processes · Fundamental principles · Goods and services · Millennium Assessment

\section{INTRODUCTION}

Ecological systems are fundamentally complicated, heterogeneous, and often structured by complex dynamical processes (Anand et al. 2010, Burkhard et al. 2010). Environmental variables influence ecological systems across a wide range of space and time scales. Understanding the complexity of natural systems is imperative if we are to understand human interactions that result in critical community shifts, loss of resilience, or changes to new equilibrium points (Steele 1996, McLeod \& Leslie 2009). Human impacts span multiple levels of biological organisation from subcellular disruption and the loss of genetic material through to landscape and ecosystem level disturbances.
Advancement in our understanding and predictive capacity will only stem from research efforts that continue to explore and explain the interactions between variables of natural systems. However, understanding and managing ecological systems are 2 distinct entities. The management of natural systems cannot conceivably wait for or incorporate all ecological information. Such attempts would be unwieldy and highly specified and would lack the ability to adapt to future challenges or to be applied in different locations. There are frequently gaps in our knowledge, but even with complete ecological understanding there will still always be areas of uncertainty (Doak et al. 2008). We argue that the ability to manage these complex systems effectively must stem from simplifications of eco- 
logical knowledge. In this paper, we discuss an 'Ecosystem Principles Approach' (EPA), a method for simplifying ecological information into management frameworks relevant to the goods and services approach.

The concept of an implicit link between human and ecological systems is often credited to Eugene Odum (Odum 1953). Since this time, national and international initiatives, such as the Study of Critical Environmental Problems (SCEP 1970), the International Biological Programme and the Convention of Biological Diversity (CBD), have served to stimulate attention on socio-ecological issues and the development of ecosystem goods and services (Daily 1997). The goods and services approach is now recognised as a useful tool in the management of ecological systems that allows us to identify and acknowledge the underlying functions of nature that support human wellbeing (de Groot 1992, Daily 1997, Daily et al. 2000). Building on these early developments, the Millennium Ecosystem Assessment (MA 2003, 2005) has served to stimulate and promote this research field, which is timely given the increasing pressures on natural ecosystems and the demands that a growing global population places on natural resources (Fig. 1, MA 2005). A key step for ecosystem goods and services research has been the definition of terminology and framework conceptualisation (de Groot et al. 2002, 2010, Steffen 2009, Paetzold et al.
2010). These valuable studies have been a necessary starting point; however, there is a need to move these concepts forward and demonstrate their value though their practical application. A key failure in the application of ecosystem services to the marine environment is that there is no extensive framework for linking ecosystems service (ES) and the service provider (SP) (Cognetti \& Maltagliati 2010, de Groot et al. 2010).

To improve ecosystem service management, there is a need to incorporate the roles that natural habitats and their resident communities play in ecosystem service generation (Carpenter et al. 2009, Norgaard 2009). The current challenge was summarised by de Groot et al. (2002, p. 394) who stated that, 'the first step in the assessment of goods and services involves the translation of ecological complexity (structure and process) into a more limited number of ecosystems functions'. Ecological elements that have been incorporated into frameworks range from biodiversity to ecosystem functions, landscape properties, and biophysical structures (de Groot et al. 2010, HainesYoung \& Potschin 2010). However, current frameworks have no clear or consistent process for organising ecological information or defining the amount of ecological detail necessary. Indeed, there are a range of interpretations for a term such as 'ecosystem function' (Jax 2005), and these vary in their implicit link to goods and

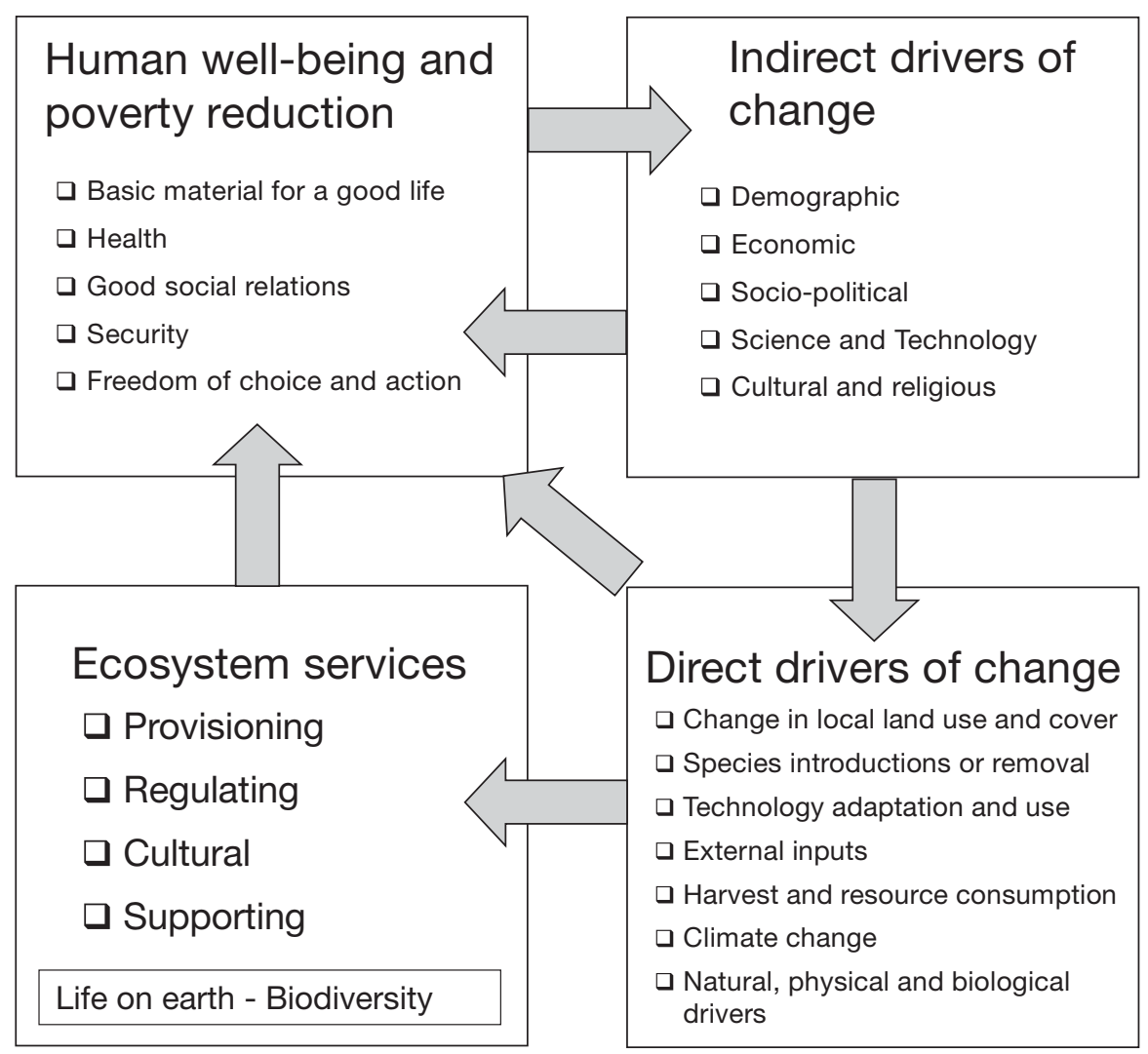

Fig. 1. Adaptation of the Millennium Assessment framework which operates at a range of spatial and temporal scales (MA 2005) 
services (de Groot et al. 2002, Wallace 2007). This poses a major obstacle in the development of universal methodology. Techniques are needed that integrate and summarise ecological complexity in ways that are clear, defensible, and scientifically underpinned but that are also easily understood, followed, and applied.

Incorporating ecological information into the framework of goods and services requires a delicate balance between complexity and simplicity. The integration of too much or too detailed ecological information into an ecosystem service assessment would cause it to be overly complicated, only relevant under specific conditions, and likely to be poorly understood outside of a small group of experts. Paradoxically, this detailfocused approach would still be limited by unknown ecological information in terms of application and predictive capacity. For example, by filtering the water column, removing particulates and reducing turbidity, shellfish can contribute to the ecosystem service of 'water clarity' in harbours (Prins et al. 1996). Multiple species perform this role, and the capacity of species to contribute to this service is influenced by contaminant effects and hydrodynamic conditions (Norkko et al. 2005, 2006). Even when considering the potential effects of contaminants alone, we need to take into account the impacts associated with concentration, reactive states, and exposure times as well as antagonistic, synergistic, or multiplicative relationships (Thrush et al. 2008a). Collectively these factors demonstrate that even a relatively simplistic ecosystem service can have high ecological complexity and create predictive uncertainty. Conversely, a lack of ecological information results in a disconnection between ecological services and the underpinning processes. If the role that organisms play in filtering the water column is unknown, then there may not be a perceived benefit in maintaining healthy habitats that support these species. Failure to understand the key ecological components negates the ability to manage ecosystem system services effectively because the consequences of management options are not linked through to service provision (i.e. failure to move from the bottom right to left of Fig. 1).

Other factors complicating the balance between simplicity and complexity in the development of ecosystem goods and service frameworks are the high levels of multi-functionality, connectivity, and interactions in marine coastal systems. A broad range of ecosystem functions are influenced by the activity of species, with a single species able to influence multiple ecosystem functions. For example, the action of a bioturbating organism inhabiting intertidal sediments influences sediment stability (Rhoads \& Young 1970, Pearson 2001, Needham et al. 2010), benthic primary productivity (Sandwell et al. 2009), inorganic nutrient exchange, the cycling of metals, and carbon storage (Smith et al. 2010). High levels of connectivity in marine systems play an important role in their operation. Coastal and estuarine ecosystems, in particular, have numerous transitions between terrestrial and aquatic, marine and freshwater, and shallow $(<1 \mathrm{~m})$ and deeper water environments. Coastal habitats can be a source of material and a repository for sediments and contaminants (Dauvin 2008). Connectivity also influences the supply of propagules and the dynamics of recovery from disturbance (Thrush et al. 2008b). High functionality and connectivity indicate that multiple variables across space and time influence system dynamics. This consequently drives us towards inclusive strategies for ecological information in ecosystem goods and services assessment. Ecosystem 'functions' have been suggested as an intermediate step to link ecological systems to their derived goods and services (MA 2003). However, a single function generally links to many ecosystems services and vice versa (see Fig. 2). This near ubiquitous level of connectivity highlights nearly all system components and confounds differentiation of important processes. Thus, the level of aggregation and simplification encapsulated by the concept of ecosystem functions per se does not demonstrate the right elements of ecosystem complexity.

High complexity in ecological systems does not preclude generality at a more simplified level. In this paper, we present a technique called the Ecosystem Principles Approach (EPA) that is a progressive way of incorporating ecology into the goods and services framework. This application circumvents many of the problems associated with ecosystem functions and multi-functionality (Fig. 2) and is effective at simplifying and integrating appropriate ecological information. In this paper, we present

- The theory behind the EPA, its design, operation, and its ability to accommodate temporal and spatial issues

- Examples of applying the EPA in a shallow marine coastal ecosystem and merit for understanding the ecological roles that underpin ecosystem services

- Use of the EPA for tracing the effects of anthropogenic stressors on ecosystem goods and services and indicating potential future scenarios.

\section{THE ECOSYSTEM PRINCIPLES APPROACH (EPA)}

The EPA focuses on general ecological principles and functional roles within habitats (Box 1, Table 1). An 'ecosystem principle' explicitly defines a key element of how we expect the ecological system to operate (when the system is not already badly degraded) and collectively produces a framework (Box 1) that can 


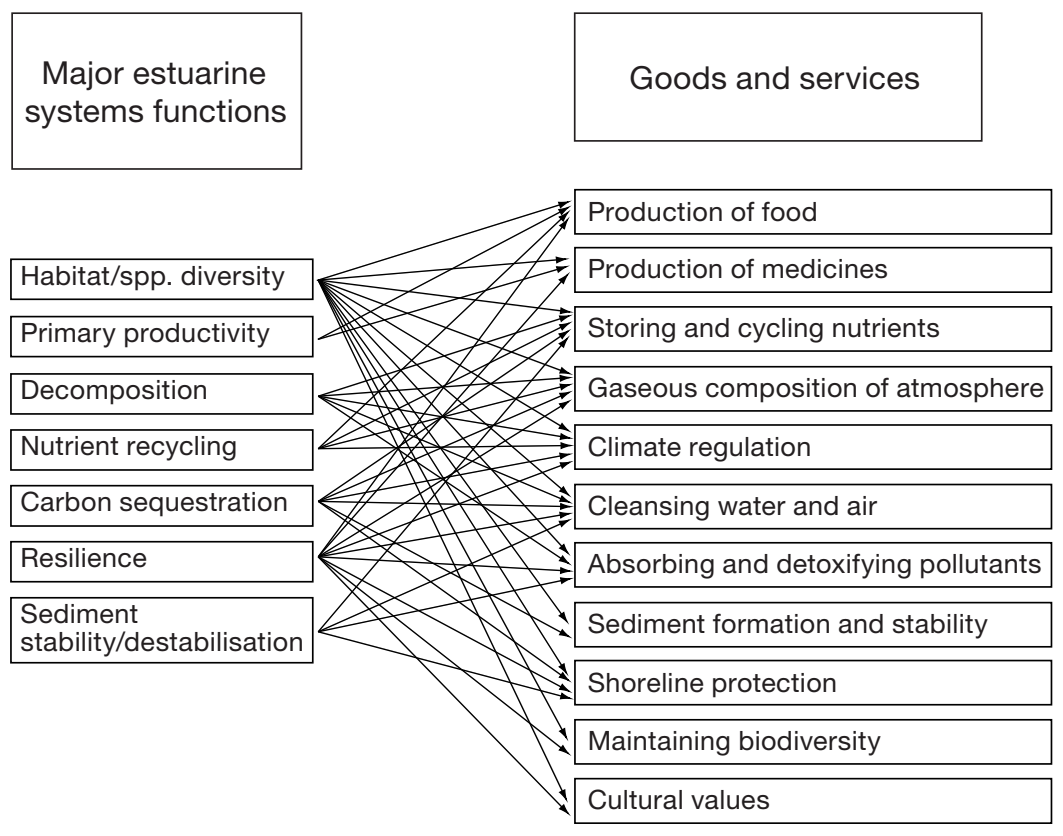

Fig. 2. Multi-ecosystem functionality and the relationships with a broad range of ecosystem services

be utilised in assessment and decision-making processes (Fig. 3). We have demonstrated this with example principles for a shallow soft-sediment, noneutrophic harbour (Waitemata Harbour, Auckland,
New Zealand) (Box 1), although this approach, with different principles, can be adapted and used for a range of ecological systems. For example, rather than stating that 'productivity' is an important prerequisite for 'food production' in Waitemata Harbour, under the EPA we use widely accepted concepts and draw attention to important aspects of this process by defining more explicitly the conditions that enhance 'productivity' and using this information to determine which habitats are important in delivering this service (Table 1). We also define the connections to other ecosystem principles. For example, when considering productivity, we focus on the importance of intertidal flats for contributing to system productivity (Sandwell et al. 2009) and the higher rates of productivity in coarser sediment (Lohrer et al. 2010). These features feed into the overall system productivity when connectivity allows (Box 1, Principles 1-3, 15 and 16; e.g. Thrush et al. 2008b). Connectivity refers to both the physical pathways that allow materials to flow within and between the defined

Box 1. Key general ecosystem principles relevant to service provision in shallow non-eutrophic estuarine and coastal areas of New Zealand

P1 Benthic productivity is an important contributor to system productivity and is greater in shallow than deeper waters.

P2 Benthic productivity is greater in sandy substrates (i.e. sediment dominated by particles in $2-0.063 \mathrm{~mm}$ size range) than muddy substrates $(<0.063 \mathrm{~mm})$.

P3 Healthy areas that maintain high productivity at low trophic levels should fuel high productivity at high trophic levels.

P4 Mudflats are predominantly involved with the storage and sequestration of organic and inorganic material. Sandflats are predominantly involved with the processing, modification and recycling of organic and inorganic material.

P5 Shallow waters where the water column is well-mixed, have higher rates of processing relative to deeper less well-mixed areas, which can be storage 'sinks' for material.

P6 Species can play a dominant role in the determination of nutrient exchange with respect to the magnitude and direction.

P7 Flora and fauna that filter food or nutrients from the water column and maintain a sedimentary lifestyle have a stabilising effect on the sediment.

P8 Organisms that have a mobile lifestyle, moving through and on the sediment surface, or those that deposit feed on the sedimentary material have a destabilising effect on the sediment.
P9 Shallow, well-mixed waters have a higher ratio of gaseous exchange than deeper, less well-mixed waters.

P10 Shallow, well-mixed waters have higher concentrations of bacteria relative to deeper, less well-mixed waters.

P11 Organisms produce and mediate habitat structures that are utilised for predation refugia and nurseries for juvenile life stages and surface area for attachment of other species.

P12 Molluscs and other organisms sequester carbon by producing shells and skeletons that create sediment over long time scales.

P13 Suspension-feeders can influence the turbidity of overlying water through their filtration activity.

P14 Increased suspended sediment concentrations reduce primary production through increased light attenuation.

P15 Connectivity is required to translocate material between different locations within a coastal area and from shallow to deeper waters.

P16 The level of connectivity influences the supply and removal rates of biotic and abiotic material.

P17 Space and resource occupancy by native species can decrease invasion risk.

P18 Higher biodiversity increases the number of functional groups and/or the range of species within a functional group. 
Table 1. Examples of ecosystem goods and services in marine coastal ecosystems and their relationship to ecological processes and the associated principles

\begin{tabular}{|c|c|c|}
\hline Services category & $\begin{array}{l}\text { Functional roles contributing } \\
\text { to services }\end{array}$ & $\begin{array}{l}\text { Associated ecosystem } \\
\text { principles }\end{array}$ \\
\hline \multicolumn{3}{|l|}{ Provisioning services } \\
\hline $\begin{array}{l}\text { Production of food } \\
\text { (wild stock, captured by } \\
\text { commercial, traditional or } \\
\text { recreational fishing; } \\
\text { aquaculture) }\end{array}$ & $\begin{array}{l}\text { Primary production } \\
\text { Secondary production } \\
\text { Trophic relationships } \\
\text { Reproductive habitats } \\
\text { Refugia for juvenile life stages } \\
\text { Ontogenetic habitat shifts } \\
\text { Biogeochemical cycles associated with enrichment and nutrient recycling } \\
\text { Biogenic habitat generators }\end{array}$ & $\begin{array}{l}\text { P1, P2, P3, P6, P11, } \\
\text { P14, P15, P16 }\end{array}$ \\
\hline Production of medicines & Maintenance of biodiversity & P1, P11, P17, P18 \\
\hline \multicolumn{3}{|c|}{ Regulating and supporting services } \\
\hline $\begin{array}{l}\text { Storing and cycling } \\
\text { nutrients }\end{array}$ & $\begin{array}{l}\text { Role of ecosystem in biogeochemical cycles } \\
\text { Role of organisms in storage and processing }\end{array}$ & $\begin{array}{l}\text { P1, P3, P4, P5, P6, } \\
\text { P12, P15, P16 }\end{array}$ \\
\hline $\begin{array}{l}\text { Gaseous composition of } \\
\text { the atmosphere }\end{array}$ & $\begin{array}{l}\text { Role of ecosystem in biogeochemical cycles } \\
\text { Role of organisms in storage and processing }\end{array}$ & $\begin{array}{l}\text { P1, P4, P5, P6, P9, } \\
\text { P10, P12, P15, P16 }\end{array}$ \\
\hline Climate regulation & $\begin{array}{l}\text { Benthic-pelagic coupling } \\
\text { Bioturbation/irrigation } \\
\text { Nutrient and carbon flux } \\
\text { Role of organisms - } \\
\text { specific species/microbes/enzymes }\end{array}$ & $\begin{array}{l}\mathrm{P} 1, \mathrm{P} 4, \mathrm{P} 5, \mathrm{P} 6, \mathrm{P} 9 \\
\mathrm{P} 10, \mathrm{P} 12, \mathrm{P} 15, \mathrm{P} 16\end{array}$ \\
\hline Cleansing water and air & $\begin{array}{l}\text { Benthic-pelagic coupling } \\
\text { Bioturbation/irrigation } \\
\text { Nutrient and carbon flux } \\
\text { Role of organisms - } \\
\text { specific species/microbes/enzymes }\end{array}$ & $\begin{array}{l}\text { P1, P4, P5, P6, P7, } \\
\text { P15, P16 }\end{array}$ \\
\hline $\begin{array}{l}\text { Absorbing and detoxify- } \\
\text { ing pollutants }\end{array}$ & $\begin{array}{l}\text { Accumulation in depositional habitats (mangroves), binding of contami- } \\
\text { nants, breakdown - } \\
\text { dehalogenating bacteria; } \\
\text { absorbers (and tissue sequesters); } \\
\text { bioturbators (burial and transport); } \\
\text { sediment stabilisers }\end{array}$ & $\begin{array}{l}\text { P1, P4, P5, P6, P15, } \\
\text { P16 }\end{array}$ \\
\hline $\begin{array}{l}\text { Sediment formation and } \\
\text { stability }\end{array}$ & $\begin{array}{l}\text { Biogenic carbonate, particle binding and aggregation } \\
\text { Role of molluscs, corals and other calcimass generators } \\
\text { Biogenic structure/reef makers } \\
\text { Plants }\end{array}$ & $\mathrm{P} 1, \mathrm{P} 5, \mathrm{P} 7, \mathrm{P} 8, \mathrm{P} 12$ \\
\hline $\begin{array}{l}\text { Shoreline protection and } \\
\text { Maintaining hydraulic } \\
\text { cycles }\end{array}$ & $\begin{array}{l}\text { Fringing vegetation (e.g. mangroves), damping flow velocity and } \\
\text { erodibility } \\
\text { Bioturbation and burrow formation } \\
\text { Shell formation and bivalve abundance } \\
\text { Species, spatial structure, size and density influences on hydraulic } \\
\text { processes }\end{array}$ & P1, P7, P8, P11 \\
\hline Habitat formation & Provision of habitat structure & P1, P7, P8, P11, P12 \\
\hline Maintaining biodiversity & $\begin{array}{l}\text { Invasibility } \\
\text { Provision of habitat } \\
\text { Maintenance of trophic structure } \\
\text { Resilience and recovery } \\
\text { Genetic resources } \\
\text { Facilitation } \\
\text { Resource use complimentarily } \\
\text { Allee effects }\end{array}$ & $\begin{array}{l}\text { P1, P3, P6, P7, P8, } \\
\text { P11, P15, P16, P17, } \\
\text { P18 }\end{array}$ \\
\hline \multicolumn{3}{|l|}{ Cultural services } \\
\hline $\begin{array}{l}\text { Cultural values } \\
\text { (recreation and tourism; } \\
\text { provision of beauty, } \\
\text { inspiration and value) }\end{array}$ & $\begin{array}{l}\text { Biodiversity } \\
\text { Ecosystem, community and population functioning } \\
\text { Functions influencing water clarity, habitat diversity } \\
\text { Delivery of services related to aesthetics, and resource use }\end{array}$ & $\mathrm{P} 1-18$ \\
\hline
\end{tabular}




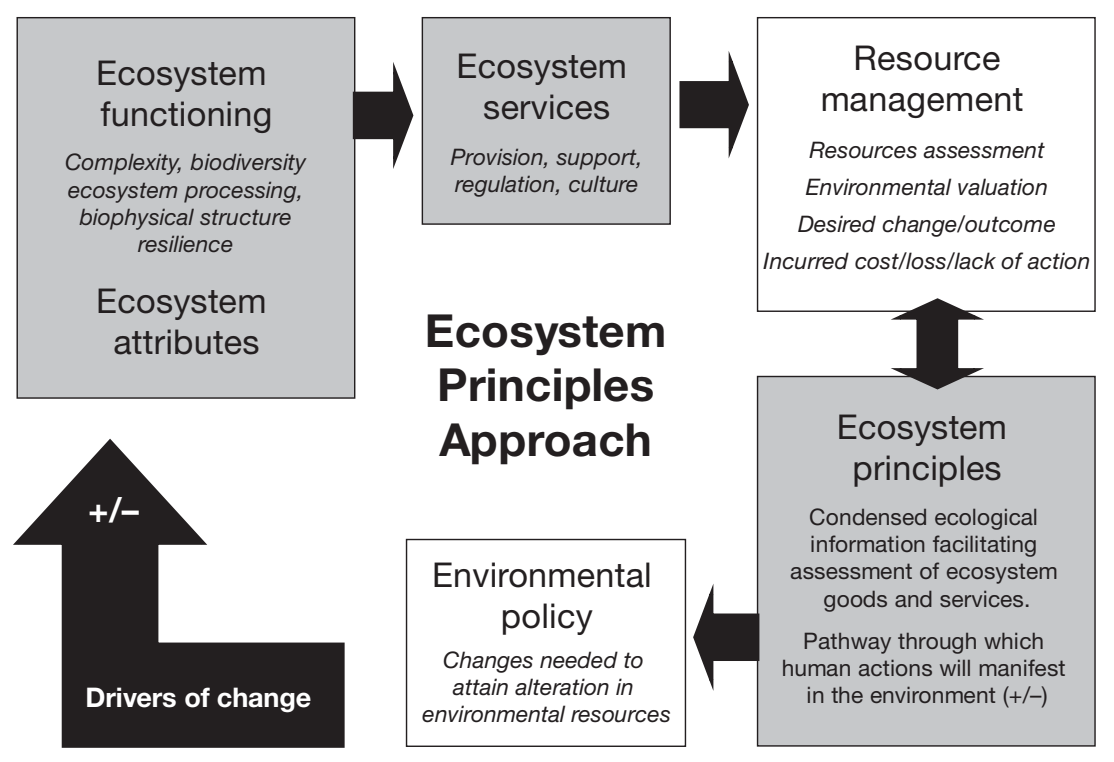

Fig. 3. The 'Ecosystem Principles Approach' framework: Ecosystem principles are used as a simplification of ecological systems (grey boxes). The ecosystem principles can be used in the resource management to assist in decision-making processes that feeds into policy (white boxes). Ecosystem principles can be used to understand how actions will impact the ecological system and improve or forfeit ecosystem service(s). Changes in ecosystem functioning/services will be detected during environmental/social monitoring by resource managers, who can decide whether further action is to be taken system and the biological connections that mediate the transfer of energy through the ecological system. Examples include the transfer of material and energy through the movement of predators and prey and through trophic connectivity. Other principles can specify the relative contributions of different locations to nutrient cycling (Box 1, Principles 4 and 5; e.g. Sundbäck et al. 1991) or the importance of biotic mediation relative to purely physical or chemical processes (Principle 6; e.g. Lohrer et al. 2004a, Needham et al. 2010). Under the EPA, important ecological properties can be included that would not necessarily be intuitively incorporated when coupling ecosystem 'functions' to services, such as the 'connectivity' principles, which define the conditions that enable other processes to occur (Box 1, Principles 15 and 16).

\section{IDENTIFICATION OF PRINCIPLES}

We have identified what we think ecologists and resource managers would agree on as 'general principles' for Waitemata Harbour, even if the strength of the underpinning functions can vary in space and time (Box 1). In our example, the principles are benthic focused because this is a highly benthic dominated system and thus our principles are fit-for-purpose. In other systems a different range of principles may need to be employed. While there may be exceptions, in essence the principles should highlight information that is widely accepted as 'general system rules' and so are defendable. While acknowledging the reality of sliding baselines in most coastal and estuarine ecosystems, principles should be reflective of a healthy system. In the first instance, we seek to identify how the ecosystem could be performing with subsequent consideration of the historical and current stresses on that system. Each principle must be both underpinned by research and defined in such a way as to ensure that it represents the collective understanding of all parties involved in their definition. A key requirement therefore is that principles are clear and easily interpreted to ensure uptake by all stakeholders. To maximise the effectiveness of the EPA, the principles should cover a broad and comprehensive range of ecological understanding (Box 1). Ensuring a broad coverage of principles minimises the attention on a single aspect of system functioning and reduces subjectivity or specific focus. The number and nature of principles employed could vary depending on the system of interest, the level of ecological understanding and the nature of management or societal questions being addressed. Many principles are common to the functioning of many ecosystems, such as connectivity, productivity, species-mediated effects, and biodiversity. Other principles will be more specific to individual systems (Box 1). Principles can cover biological interactions with physical and chemical parameters and differentiate functioning between different areas or specific habitats. A key aspect of the EPA is that the identified principles genuinely reflect a broad representation of system functioning to avoid bias for specific aspects or services (e.g. fisheries production). In identifying principles we recommend an open and inclusive process involving a wide range of expertise (e.g. scientific, traditional knowledge, management) and stakeholders. This should ensure a wide understanding of system functioning, minimise subjectivity, and maximise use for assessing multiple ecosystem services. 


\section{STRENGTHENING ECOLOGICAL LINKS TO ECOSYSTEM SERVICES: APPLICATION OF THE EPA}

Table 1 indicates more explicitly the ecological and spatial-temporal contexts that lead to service generation and identifies certain qualifying conditions. Table 1 facilitates the understanding of goods and services because the ecological principles describe the conditions required for the ecological system to operate. The frequency of occurrence of each principle across a range of services can be used to identify key elements of the ecological system, such as the importance of particular species or habitats (e.g. shellfish or mangroves), defined areas (e.g. mid-harbour locations), or of qualifying conditions (e.g. processes that occur when temperature is above $10^{\circ} \mathrm{C}$ ). In addition, the range of principles involved in the production of a particular ecosystem good or service can be used to assess the level of multi-functionality. A greater number of associated principles is an indication of a broader range of processes involved in service generation and suggests which particular services may be most susceptible to disruption.

\section{EPA APPLICATION: A NEW ZEALAND SOFT SEDIMENT MARINE COASTAL SYSTEM}

\section{Provisioning services}

Table 1 demonstrates that provisioning services in Waitemata Harbour are logically linked to the ecological principles relating to productivity. Beyond this, Table 1 emphasises that nutrient regeneration is an important prerequisite underpinning primary production (under non-eutrophic conditions) and that the activity of species facilitates nutrient flux. Intertidal areas are highlighted as significant contributors to system productivity. For management, the principles express the value of habitat-specific productivity for system functioning. Human use of provisioning resources focuses on the higher trophic levels of shellfish and fish (in our system typically cockles, oysters, pipi, and snapper). The principles highlight that concern for system productivity must include consideration of the maintenance of healthy intertidal areas, which contribute to this service and connectivity from lower to higher trophic levels as well as from shallow to deeper waters (Box 1).

\section{Regulating and supporting services}

The EPA, which is underpinned by an understanding of the functional role of different habitats (Table 1), demonstrates that supporting and regulating services comprise a wide range of different processes. These services are typically highly multi-functional, with a high number of principles linked to each service (Table 1). Many of these services are broad-scale and operate across habitats. The principles approach highlights compartmentalisation for processing and storage functions between shallow and deeper coastal water habitats (Table 1). Intertidal areas are foci where material can be processed, and these areas play a role in influencing productivity and gaseous exchange. For management, the ecosystem principles emphasise the importance of shallow areas for nutrient cycling but also that nutrient cycling is a supportive component for multiple services (Table 1, high frequency of principles 4 and 5). The principles and the functional roles within habitats identify hotspots for carbon sequestration and shoreline protection, such as shellfish beds and fringing plant communities, e.g. mangroves (Avicennia marina).

\section{Cultural services}

Cultural services should reflect a diverse range of usages and values and consequently are likely to link to all ecosystem principles that collectively synopsize a functional system (Table 1). Although individual cultural services are likely to weight the importance of principles differently, this is beyond the scope of our example. For management, the output of the principles approach can be combined with social preferences to evaluate the balance or discrepancies between service supply and use. In the region where these principles have been applied (Auckland, New Zealand), discrete choice modelling has revealed that water clarity, the quality of underfoot conditions, and ecological health are most valued community preferences (Batstone \& Sinner 2010). This study also found a strong preference and a greater willingness to pay for improvements to locations in the outer regions of coast relative to middle and upper harbour sections. The principles approach, which emphasises the importance of middle harbour habitats, clearly demonstrates a separation between where services are generated and where services are most valued. Separation between services provision and uptake is an acknowledged issue in goods and service research (Fisher et al. 2009) although direct examples are scarce. For management, this separation demonstrates that the perceived lower valued areas may be fundamentally important in service provision and suggests caution for the management of these areas that are often the repository for contaminants. This also suggests a need for education and the broadening of societal values with respect to natural systems. 


\section{USING THE EPA TO TRACE THE IMPACT OF DISTURBANCES ON ECOSYSTEM SERVICES}

A key aspect of managing the relationship between ecosystem functioning and goods and services is the need to understand and identify how human impacts modify these relationships. Understanding the precise nature of anthropogenic stressors has high uncertainty in complex ecological systems with cumulative effects, thresholds and multiple interactions at different levels of system organisation (Hinz et al. 2009, Lundquist et al. 2010). However, the EPA can be used to list the general effects of stressors to link existing ecosystem principles to goods and services. For example, the impact of elevated sediment loading is a serious problem in many New Zealand estuaries and harbours, as well as other parts of the world (Lohrer et al. 2004b). Chronic sedimentation causes elevated turbidity and increases the muddiness of intertidal sediment flats. Over time this causes homogenisation and fragmentation and ultimately decreased habitat diversity (Thrush et al. 2008b). Associated with these changes in habitat are decreases in the ecological connectivity of mature communities and the reduced abundance of shellfish and large organisms (Peterson 1985, Thrush et al. 2003). Linking to the principles, the loss of larger organisms reduces the potential for biotically mediated processes and the ability of habitats to sequester carbon in shell formation (Box 1). Habitat fragmentation that results in reduced connectivity can impact a wide range of regulatory services that ultimately affect productivity and resilience (Box 1, Table 1). The principles indicate that potential disruption to goods and services is broad; however, a service such as shoreline protection may be comparatively less affected (Table 1). By linking the pathways of stressor effects, the EPA can indicate where particular ecosystem services may increase or decrease in response to human activity. This can feed into the social aspects of goods and services research, e.g. discrete choice model and valuation (Hensher et al. 2005), and suggest potential environmental future scenarios. For example, the importance of nutrient cycling or disruption of this process might be emphasised using the principles approach in terms of the mitigation and reduction in the risk of harmful algal blooms.

\section{DISCUSSION}

Understanding ecological complexity is central to our ability to understand and manage natural systems. Although natural systems are complicated, we cannot identify any ecological functions that do not ultimately contribute to the ecological goods and services in some capacity. Rising global populations are transforming many ecological systems at a rate for which the changes to these environments are unknown and the ability to make predictions is lacking (Carpenter et al. 2009). Overcoming ecological complexity and substantial uncertainty are at the centre of resource management, which must inevitably proceed with imperfect information. For effective solutions, science must work cooperatively with management and society by providing information in a format that is clearly communicated and easily integrated into management actions. Simplifications of natural systems are imperative in this situation, and approaches that transcend the sciencemanagement divide may be the most effective at protecting ecological goods and services.

As a pragmatic solution, we have presented the EPA based on a simplification of natural systems using accepted general principles. Despite its simplicity, the EPA retains the ability to include a diverse range of functional and structural system elements (Table 1). Consequently, it incorporates elements of ecological complexity and uncertainty that are typically excluded from management as being too difficult or too esoteric to tackle. We have demonstrated links between ecosystem goods and services in a marine coastal environment and the underlying ecological attributes in a format that is useful to management. The main strengths of this approach are its ability to incorporate ecological information that can transcend spatial and temporal scales, as no single scale is correct for either our ecological understanding or management (McLeod \& Leslie 2009). The approach can be easily understood by a broad audience and has a solid scientific grounding. A caveat of the EPA is that generalities will not always hold true, and we must learn how to identify important exceptions. But principles can be refined over time and adapted as new information is incorporated; for example, Barbier et al. (2010) recently identified the services provided by 5 coastal marine habitats and discussed functions important in service generation. New information provides new insight for these specific habitats, but the 5 habitats identified by Barbier et al. (2010) do not encompass the range of habitats representative of a typical coastal ecosystem (such as a harbour or embayment). The insights generated by research on selected habitats are valuable and can be used within the EPA (e.g. see Table 1). However, our analysis highlights that broader system processes such as connectivity must be included for a complete assessment of ecosystem services and their relationship to specific locations. Selection of the principles is an important step that should involve a range of knowledge to cover a comprehensive system understanding and avoid subjectivity. This process should include a peer review mechanism to validate the selection. 
GIS mapping applications are an effective way of visualising spatial differences in the quantity, quality, and connectivity of services (Troy \& Wilson 2006, Meyer \& Grabaum 2008, Pert et al. 2010). However, the mapping of communities, habitats, or ecosystem processes is highly data driven and the detail is not always available. There are examples of the use of surrogate information in terrestrial systems, which can be mapped as a proxy for services (e.g. Yapp et al. 2010). Terrestrial systems have a higher proportion of 'in situ' services in which the point of service provision is the same as the location of utilisation, making mapping more straightforward (Richmond et al. 2007, Costanza 2008). Mapping of marine services may prove more difficult due to the diverse and spatially widespread functions that underpin them. Approaches like the EPA could be adapted in marine systems to use the best available knowledge and general understanding of system functioning to highlight areas important in service provision. For example, even with basic bathymetry and sediment data and access to software like Google Earth (which can indicate the distribution of coastal vegetation), multiple ecosystem principles, which are linked to services (Table 1), could be mapped. It is clear, however, from Box 1 that the ecological principles differ in the extent to which they can be spatial defined and mapped. Further consideration will be necessary to translate the EPA into a mapping context and to prevent biasing of specific principles and incorporation of services that are less spatially explicit. As marine management and policy becomes more spatially explicit, mapping the EPA could be a useful first approach in locations when there is an absence of local empirical information but there is a general understanding for the type of ecological system.

A challenge for integrating science into policy is the need for buy-in from the general public in democratic societies. Education is a key aspect to convey the necessary reasoning behind decision making, especially if the choices are hard or appear counterintuitive. In Waitemata Harbour, human preference had been indicated for outer coastal locations (Batstone \& Sinner 2010), but the EPA indicates that the provision of many services is underpinned by inner to mid-harbour habitats (Table 1). Higher investment of tax-payers' money in areas that are of perceived lower value is likely to be met with a level of antagonism, unless the importance of the ecological processes in these areas can be conveyed. Many people are still not conscious of the benefits obtained from natural systems (Daily 1997). This indicates a greater need for ecologists to work more closely with social scientists. Trans-disciplinary approaches would provide ecologists with the opportunity to convey key aspects of ecological functioning using tools such as the EPA and also better understand the range of human choices and values that collectively need to be integrated into management approaches. We recognise the importance of various monetary valuation techniques (Ledoux \& Turner 2002) to draw attention to goods and services, but with imperfect knowledge, valuation often picks up the service appreciation only. We advocate for integrative approaches that convey the importance of long-term service generation against short-term exploitation. While there is a need to recognise the value of ecosystem services, we must better understand the links between services and the ecological underpinning. These approaches are complementary and necessitate moving forwards from the perspective that we must often demonstrate economic value to increase the argument for protecting a service, but we can only protect it if we understand how it is formed.

We have used the EPA to demonstrate how ecological information can be simplified into a format that can advise policy and management without excluding or getting bogged down in the detail. Our approach can highlight the importance of specific habitats but does not lose sight of the wider ecological processes that are also of fundamental importance. A major value of the EPA is that it aligns with the philosophy of 'EcosystemBased Management' (EBM; McLeod \& Leslie 2009). Key principles of EBM are (1) ecosystems offer a broad range of services, (2) spatial scale is a key issue in management, (3) there is a need to integrate across different areas (4) there is a need to account for cumulative impacts, and (5) that decisions must be made despite uncertainty (McLeod \& Leslie 2009). Ecosystem-based management is an integrated approach that considers the entire system and is by its very nature a challenge because it emphasizes the importance of interactions rather than dealing with issues in isolation (Christensen et al. 1996). Nevertheless, as illustrated by the EPA the high level of multi-functionality and connectivity between goods and services in marine coastal systems reinforces the dangers of cumulative thresholds and sharp broad-scale decline in service provision. Stressors which cause deterioration in ecological health will have broad consequences for service delivery, but efforts to restore or improve ecological health have the potential to cause similarly wide increases in benefits.

\section{CONCLUSIONS}

Across all ecosystems, goods and service research is lagging behind in the marine environment. Nevertheless, studies addressing the importance of specific habitats for service provision (Barbier et al. 2010), human preference for different benefits (McVittie \& Moran 2010) and economic value (Beaumont et al. 
2008) are increasing awareness of the benefits derived from costal ecosystems. However, gaps remain in the link between ecosystem processes and service generation which is complicated further by ecological complexity and different scales of service delivery. We have shown through EPA that it is possible to use a simple and holistic approach to link ecosystem functioning to goods and service generation in a way that is informative for management. By highlighting the ecological conditions that lead to service provision, we can more effectively target, preserve, and improve the management of natural systems and the benefits generated from them.

Scientists have a predisposition to focus on unknown rather than known information, which is an inseparable part of the vocation. For science to translate into policy we must focus on what is known about ecological systems, while allowing room for frameworks to adapt and future information to be incorporated. Ecologists should be the best people to translate ecological literature into formats suitable for other branches of science and management, i.e. social science, and for other disciplines. This is something we must embrace to maximise the uptake of ecology into management frameworks and to ensure the greatest possibility of sustaining resources for ourselves and future generations.

Acknowledgements: We thank J. Hewitt, D. Lohrer (NIWA), and J. Walker (AC) for help with idea development. This work was supported by FRST C01X0501 in partnership with the Auckland Council. Open Access for the Theme Section on Coastal Zone Management is sponsored by the Marine Alliance for Science and Technology for Scotland (MASTS) Coastal Zone Joint Research Theme.

\section{LITERATURE CITED}

Anand M, Gonzalez A, Guichard F, Kolasa J, Parrott L (2010) Ecological systems as complex systems: challenges for an emerging science. Diversity 2:395-410

Barbier E, Hacker S, Kennedy C, Koch E, Stier A, Silliman B (2010) The value of estuarine and coastal ecosystem services. Ecol Monogr 81:1521-1531

Batstone S, Sinner J (2010) Techniques for evaluating community preferences for managing coastal ecosystems. Auckland region stormwater case study, discrete choice model estimation. Report no. 2010/012, Cawthron Institute for Auckland Regional Council, Auckland

Beaumont NJ, Austen MC, Mangi SC, Townsend M (2008) Economic valuation for the conservation of marine biodiversity. Mar Pollut Bull 56:386-396

Burkhard B, Petrosillo I, Costanza R (2010) Ecosystem services-bridging ecology, economy and social sciences. Ecol Complex 7:257-259

Carpenter SR, Mooney HA, Agard J, Capistrano D and others (2009) Science for managing ecosystem services: beyond the Millennium Ecosystem Assessment. Proc Natl Acad Sci USA 106:1305-1312
Christensen NL, Bartuska A, Brown JH, Carpenter S and others (1996) The report of the Ecological Society of America Committee on the scientific basis for ecosystem management. Ecol Appl 6:665-691

Cognetti G, Maltagliati F (2010) Ecosystem service provision: an operational way for marine biodiversity conservation and management. Mar Pollut Bull 60:1916-1923

Costanza R (2008) Ecosystem services: multiple classification systems are needed. Biol Conserv 141:350-352

Daily GC (ed) (1997) Nature's services: societal dependence on natural ecosystems. Island Press, Washington, DC

> Daily GC, Soderqvist T, Aniyar S, Arrow K and others (2000) The value of nature and the nature of value. Science 289:395-396

Dauvin JC (2008) The main characteristics, problems, and prospects for western European coastal seas. Mar Pollut Bull 57:22-40

de Groot RS (1992) Functions of nature, evaluation in environmental planning, management and decision making. Wolters-Noordhoff, Groningen

de Groot RS, Wilson MA, Boumans RMJ (2002) A typology for the classification, description and valuation of ecosystem functions, goods and services. Ecol Econ 41:393-408

de Groot RS, Alkemade R, Braat L, Hein L, Willemen L (2010) Challenges in integrating the concept of ecosystem services and values in landscape planning, management and decision making. Ecol Complex 7:260-272

Doak DF, Estes JA, Halpern BS, Jacob U and others (2008) Understanding and predicting ecological dynamics: are major surprises inevitable? Ecology 89:952-961

Fisher B, Turner RK, Morling P (2009) Defining and classifying ecosystem services for decision making. Ecol Econ 68:643-653

Haines-Young R, Potschin M (2010) The links between biodiversity, ecosystem service and human well-being. In: Raffaelli D, Frid C (eds) Ecosystem ecology: a new synthesis. Cambridge University Press, Cambridge

Hensher D, Rose J, Green W (2005) Applied choice analysis: a primer. Cambridge University Press, Cambridge

Hinz H, Prieto V, Kaiser MJ (2009) Trawl disturbance on benthic communities: chronic effects and experimental predictions. Ecol Appl 19:761-773

> Jax K (2005) Function and "functioning" in ecology: what does it mean? Oikos 111:641-648

> Ledoux L, Turner RK (2002) Valuing ocean and coastal resources: a review of practical examples and issues for further action. Ocean Coast Manag 45:583-616

Lohrer AM, Thrush SF, Gibbs MM (2004a) Bioturbators enhance ecosystem function through complex biogeochemical interactions. Nature 431:1092-1095

Lohrer AM, Thrush SF, Hewitt JE, Berkenbusch K, Ahrens M, Cummings VJ (2004b) Terrestrially derived sediment: response of marine macrobenthic communities to thin terrigenous deposits. Mar Ecol Prog Ser 273:121-138

Lohrer AM, Halliday NJ, Thrush SF, Hewitt JE, Rodil IF (2010) Ecosystem functioning in a disturbance-recovery context: contribution of macrofauna to primary production and nutrient release on intertidal sandflats. J Exp Mar Biol Ecol 390:6-13

Lundquist CJ, Thrush SF, Coco G, Hewitt JE (2010) Interactions between disturbance and dispersal reduce persistence thresholds in a benthic community. Mar Ecol Prog Ser 413:217-228

MA (Millennium Ecosystem Assessment) (2003) Ecosystem and human well-being: a framework for assessment. Island Press, Washington, DC

MA (Millennium Ecosystem Assessment) (2005) Ecosystem 
and human well-being: current state and trends. Island Press, Washington, DC

McLeod KL, Leslie HM (2009) Ecosystem-based management for the oceans. Island Press, Washington, DC

McVittie A, Moran D (2010) Valuing the non-use benefits of marine conservation zones: an application to the UK Marine Bill. Ecol Econ 70:413-424

Meyer BC, Grabaum R (2008) MULBO: Model framework for multicriteria landscape assessment and optimisation. A support system for spatial land use decisions. Landscape Res 33:155-179

Needham HR, Pilditch CA, Lohrer AM, Thrush SF (2010) Habitat dependence in the functional traits of Austrohelice crassa, a key bioturbating species. Mar Ecol Prog Ser 414:179-193

Norgaard RB (2009) Ecosystem services: from eye-opening metaphor to complexity blinder. Ecol Econ 69:1219-1227

> Norkko J, Pilditch CA, Thrush SF, Wells RMG (2005) Effects of food availability and hypoxia on bivalves: the value of using multiple parameters to measure bivalve condition in environmental studies. Mar Ecol Prog Ser 298:205-218

> Norkko J, Hewitt JE, Thrush SF (2006) Effects of increased sedimentation on the physiology of two estuarine softsediment bivalves, Austrovenus stutchburyi and Paphies australis. J Exp Mar Biol Ecol 333:12-26

Odum EP (1953) Fundamentals of ecology. W. B. Saunders, Philadelphia, PA

Paetzold A, Warren PH, Maltby LL (2010) A framework for assessing ecological quality based on ecosystem services. Ecol Complex 7:273-281

Pearson TH (2001) Functional group ecology in soft-sediment marine benthos: The role of bioturbation. Oceanogr Mar Biol Annu Rev 39:233-267

Pert PL, Butler JRA, Brodie JE, Bruce C and others (2010) A catchment-based approach to mapping hydrological ecosystem services using riparian habitat: a case study from the wet tropics, Australia. Ecol Complex 7:378-388

Peterson CH (1985) Patterns of lagoonal bivalve mortality after heavy sedimentation and their paleoecological significance. Paleobiology 11:139-153

Prins TC, Smaal AC, Pouwer AJ, Dankers N (1996) Filtration and resuspension of particulate matter and phytoplankton on an intertidal mussel bed in the Oosterschelde estuary (SW Netherlands). Mar Ecol Prog Ser 142:121-134

Rhoads DC, Young DK (1970) The influence of deposit-feeding organisms on sediment stability and community trophic

Submitted: December 20, 2010; Accepted: March 4, 2011 structure. J Mar Res 28:150-178

> Richmond A, Kaufmann RK, Mynenib RB (2007) Valuing ecosystem services: a shadow price for net primary production. Ecol Econ 64:454-462

Sandwell DR, Pilditch CA, Lohrer AM (2009) Density dependent effects of an infaunal suspension-feeding bivalve (Austrovenus stutchburyi) on sandflat nutrient fluxes and microphytobenthic productivity. J Exp Mar Biol Ecol 373: $16-25$

Smith AM, Wood ACL, Liddy MFA, Shears AE, Fraser CI (2010) Human impacts in an urban port: the carbonate budget, Otago Harbour, New Zealand. Estuar Coast Shelf Sci 90: $73-79$

> Steele JH (1996) Regime shift in fisheries management. Fish Res 25:19-23

Steffen W (2009) Interdisciplinary research for managing ecosystem services. Proc Natl Acad Sci USA 106:13011302

Study of Critical Environmental Problems (SCEP) (1970) Man's impact on the global environment. MIT Press, Cambridge

Sundbäck K, Enoksson V, Granéli W, Pettersson K (1991) Influence of sublittoral microphytobenthos on the oxygen and nutrient flux between sediment and water: a laboratory continuous-flow study. Mar Ecol Prog Ser 74:263-279

Thrush SF, Hewitt JE, Norkko A, Cummings VJ, Funnell GA (2003) Macrobenthic recovery processes following catastrophic sedimentation on estuarine sandflats. Ecol Appl 13:1433-1455

Thrush SF, Hewitt JE, Hickey CW, Kelly S (2008a) Multiple stressor effects identified from species abundance distributions: interactions between urban contaminants and species habitat relationships. J Exp Mar Biol Ecol 366: 160-168

Thrush SF, Halliday J, Hewitt JE, Lohrer AM (2008b) The effects of habitat loss, fragmentation, and community homogenization on resilience in estuaries. Ecol Appl 18: $12-21$

> Troy A, Wilson MA (2006) Mapping ecosystem services: practical challenges and opportunities in linking GIS and value transfer. Ecol Econ 60:435-449

Wallace KJ (2007) Classification of ecosystem services: problems and solutions. Biol Conserv 139:235-246

Yapp G, Walker J, Thackway R (2010) Linking vegetation type and condition to ecosystem goods and services. Ecol Complex 7:292-301

Proofs received from author(s): June 5, 2011 